\title{
Reliable and Sensitive Stability Indicating Assay Method of Armodafinil
}

\author{
CN Prathyusha Naik, KB Chandra Sekhar \\ Department of Chemistry, JNT University (JNTUA), Anantapuramu, Andhra Pradesh, INDIA.
}

\begin{abstract}
Objective: A reliable RP-HPLC SIAM (stability indicating assay method) was developed for the approximation of armodafinil in presence of its degradation product in pharmaceutical dosage forms. Materials and Methods: Mobile phase composition of water and methanol $(10 \% \mathrm{~V} / \mathrm{v}$ OPA) $55: 45 \% \mathrm{v} / \mathrm{v}$ was used for separation by using $C_{8^{\prime}}(250 \times 4.6 \mathrm{~mm}$, $5 \mu \mathrm{m})$ column. Eluents were detected at $225 \mathrm{~nm}$ at $1 \mathrm{ml} / \mathrm{min}$. Stress studies were performed using acid, base, oxidizing agents, light, and heat to get sufficient degradation about $10-20 \%$. Results: A total of six degradation products were detected and were well separated from active drug. The linearity was found in between $10-150 \mathrm{mcg} / \mathrm{ml}$. The LOD, LOQ were found as $0.78,2.37 \mu \mathrm{g} / \mathrm{ml}$ respectively. The \% RSD for precision study was less than $2 \%$ the accuracy by the recovery study was $98-102 \%$. The ARM was found to more sensitive to base hydrolysis followed by acid and photolytic degradation. In acid hydrolysis, four major degradants and rest of them are stress sensitive. Conclusion: It is concluded that the developed method
\end{abstract}

is a specific stability indicating assay, suitable to quantify armodafinil in presence of six degradants. Notably, this method represented degradation product even in thermal and oxidation stress unlike other reported methods.

Key words: Armodafinil, Stability indicating, RP-HPLC method, Degradation studies.

\section{Correspondence}

K B Chandra Sekhar, Department of Chemistry, JNT University (JNTUA), Anantapuramu, Andhra Pradesh, INDIA.

Phone: 0091-8309273398

Email: krishdolly@gmail.com

DOI: 10.5530/jyp.2018.10.13

\section{INTRODUCTION}

Armodafinil (ARM) (Figure 1), chemically (-) -2-[(R)-(diphenyl methyl) sulfinyl] acetamide, is used in narcolepsy treatment. It is caused by dysfunction of the orexins, whose neurons are activated by ARM. ARM acts by inhibiting the dopamine reuptake leading to an increased dopamine levels. ${ }^{1,2,3}$ Because of absence of euphoric or pleasurable effects, ARM has less potential for abuse. ARM has partial alpha 1B-adrenergic agonist effects by stimulating the receptors directly., ${ }^{4,5}$

ARM is ' $R$ ' isomer of modafinil. Few stabilities indicating method such as HPLC. ${ }^{6}$ HPTLC. ${ }^{7}$ have been reported for modafinil. But those studies were incomplete and did not reveal degradation profile. Literature revealed that methods such as Chiral HPLC. ${ }^{8}$ LC-MS/MS. ${ }^{9,} 10$ were available for quantification of armodafinil in dosage forms. In fact, modafinil and ARM are structurally similar; there is a necessity to develop new stability indicating assay method for individual isomers. It may due to the disparity in degradations kinetics among isomers or between optically pure isomer and racemic mixture. Few literatures revealed that there is significant difference between enantiomers in both degradation pathway and products. ${ }^{11,12}$ herein we report a new RP-HPLC SIAM for the estimation of ARM. The developed method is validated as per ICH Q2 (R2) Guidelines..$^{13,14}$ There are few methods reported. ${ }^{16,17,18,19}$ for ARM in literature, but have revealed no degradation in thermal and oxidation conditions or there was no compliance for degradation studies as per regulatory requirements. In earlier reports there were only 5 degradants reported. However, those methods were not completely validated. Hence, the proposed method could be complete guidance for stability indicating assay of ARM. The carcinogenicity studies for armodafinil was carried out in rat, was considered only marginally adequate as per FDA.

\section{MATERIALS AND METHODS}

\section{Materials and Reagents}

ARM (99.80\%) was a gift sample from Aurobindo Pharma limited, Hyderabad, India. Water, methanol (HPLC grade), and ammonia (analytical grade) were purchased from Merck, India. Borosilicate (Class - A) glass wares were used. All glasswares used were sterilized in hot air oven whenever necessary. All solution was freshly prepared. The ARM API obtained was authenticated by UV and IR spectra.

\section{Apparatus and chromatographic conditions}

HPLC system (Waters 2695 (Alliance) Model) with PDA detector was used. SYSTONIC Model: S-926 UV- Visible double beam spectrophotometer was used for measurements of all spectra. Chromatographic separation was performed using $\mathrm{C}_{8}(250 \times 4.6 \mathrm{~mm}, 5 \mu \mathrm{m})$. The mobile phase consisted of water: methanol ( $10 \%$ OPA) $(55: 45 \mathrm{v} / \mathrm{v})$ and was pumped at $1 \mathrm{ml} / \mathrm{min}$ flow rate. The column condition maintained at ambient temperature and UV detection was set at $225 \mathrm{~nm}$. Samples were introduced to HPLC column injector through a Rheodyne fitted with a $20 \mu \mathrm{l}$ loop.

\section{Stress studies of armodafinil}

Stress studies of ARM drug substance was carried out under Water $(\mathrm{pH} 7)$, acid $(0.1 \mathrm{~N} \mathrm{HCl} 8 \mathrm{~h})$, alkaline $(0.01 \mathrm{~N} \mathrm{NaOH} 2 \mathrm{~h})$, oxidative $\left(3 \% \mathrm{H}_{2} \mathrm{O}_{2} 4\right.$ days), thermal $\left(100^{\circ} \mathrm{C}, 5\right.$ days) and photolytic (under sunlight for $48 \mathrm{~h}$ ) stress conditions.

\section{Preparation of Stock Solution for stress studies}

A $10 \mathrm{mg}$ ARM was weighed and transferred to volumetric flask of $10 \mathrm{ml}$ capacity. Add small quantity of methanol for solubility of ARM completely and make up with $0.1 \mathrm{~N} \mathrm{HCL}, 3 \% \mathrm{H}_{2} \mathrm{O}_{2}$ and $0.01 \mathrm{~N} \mathrm{NAOH}$ to get $1000 \mu \mathrm{g} / \mathrm{ml}$. Thermal stress studies were carried out by heating 
samples in hot air oven, at $100^{\circ} \mathrm{C}$ over a period. Photo degradation was done by exposing the liquid sample $(1000 \mu \mathrm{g} / \mathrm{ml})$ under hot sunny light.

\section{Hydrolysis stress studies}

The $1000 \mu \mathrm{g} / \mathrm{ml}$ stock solutions were prepared in Basic $(0.01 \mathrm{~N} \mathrm{NaOH})$, Acidic $(0.1 \mathrm{~N} \mathrm{HCl})$ and water $(\mathrm{pH} 7)$ at room temperature. Samples of $1 \mathrm{ml}$ were taken from stock solutions at specific intervals of time and made to $100 \mu \mathrm{g} / \mathrm{ml}$ with mobile phase. The $\mathrm{pH}$ of acidic sample was adjusted to 3 Ammonia $\left(\mathrm{NH}_{3}\right)$ and $\mathrm{pH}$ of basic sample was adjusted to $\mathrm{pH} 3.0$ with glacial acid. After adjusting the $\mathrm{pH}$, the sample was injected onto HPLC column with appropriate control and blank solutions.

\section{Oxidation}

The sample for oxidation stress studies $(1000 \mu \mathrm{g} / \mathrm{ml})$ were prepared in $3 \% \mathrm{H}_{2} \mathrm{O}_{2}$. Sample of $1 \mathrm{ml}$ was withdrawn from stock solution and made to $100 \mu \mathrm{g} / \mathrm{ml}$ with mobile phase and injected onto HPLC column at different time intervals against blank.

\section{Thermal stress studies}

Thermal degradation studies were performed by exposing the solid sample to $100^{\circ} \mathrm{C}$. At varied intervals of time $10 \mathrm{mg}$ of the samples were taken and made to $100 \mu \mathrm{g} / \mathrm{ml}$ and injected.

\section{Photo degradation}

$1000 \mu \mathrm{g} / \mathrm{ml}$ ARM in water was exposed to direct sunlight for $48 \mathrm{~h} .1 \mathrm{ml}$ of samples were taken at varied time and made to $100 \mathrm{mcg} / \mathrm{ml}$ and injected onto the system with appropriate blanks.

\section{RESULTS}

The optimized condition was done by using $\mathrm{C}_{8}$ column, $\mathrm{pH} 3$ mobile phase, water and methanol (10\%OPA) within the ratio of 55:45 \% v/v at 225 wavelengths. In Figure 2 the optimized chromatogram was shown. Totally there were 6 degradants observed during stress studies with RT of $4.4 \mathrm{~min}$ (D1), $6.6 \mathrm{~min}$ (D2), 9.8 min (D3), 10.4min (D4), $13.3 \mathrm{~min}$ (D5) and $15.7 \mathrm{~min}$ (D6) respectively. In acid stress studies four degradants were formed (D3, D4, D5, D6), base stress studies - one degradant (D1), photolytic studies - one degradant(D6), Oxidative stress studies - one degradant(D2), Thermal stress studies - one degradant(D4). Out of 6 degradants D1, D2, D4 are specific to base, oxidation, thermal respectively. D6 is common degradant in both acid and photolytic stress studies. All peaks have resolution more than 2 . In Table 5 the \%degradation was shown.

\section{Validation Parameters}

As per ICH (Q2) guidelines method was validated regarding to specificity, accuracy, linearity, precision, robustness, LOD, LOQ and shown in Table 4.

\section{Specificity and Selectivity}

Specificity and selectivity was there for all degradants which were obtained during stress studies. All degradants were separated properly from ARM, so that the method is specific.

\section{Linearity and range}

ARM linearity was studied in the range of $10-150 \mathrm{mcg} / \mathrm{ml}$ at six different concentrations such as $10,20,40,60,80,100,120,150 \mu \mathrm{g} / \mathrm{ml}$. $\mathrm{R}^{2}$ value was found to be 0.9994 as shown in Table 1 .

\section{Accuracy}

Recovery studies using spike method was performed for Accuracy by using lactose solution to prove specificity in presence of excipients. Study was conducted at 80, 100 and $120 \%$ levels as detailed in the Table 2. Recovery results were in between 99.37 to $100.3 \%$.

\begin{tabular}{ccc} 
Table 1: Linearity Range Data for Armodafinil. \\
\hline Concentration $(\mu \mathrm{g} / \mathrm{ml})$ & Peak area Mean \pm SD $(\mathrm{n}=3)$ & $\%$ RSD \\
\hline 10 & $1534696 \pm 12813$ & 0.83 \\
20 & $3086506 \pm 3655$ & 0.11 \\
40 & $6191672 \pm 8087$ & 0.13 \\
60 & $9130919 \pm 10685$ & 0.11 \\
80 & $12250248 \pm 39298$ & 0.32 \\
100 & $15345283 \pm 137657$ & 0.89 \\
120 & $18678534 \pm 109555$ & 0.58 \\
150 & $22926079 \pm 55633$ & 0.24 \\
\hline
\end{tabular}

$\% \mathrm{RSD}=$ relative standard deviation; $\mathrm{SD}=$ standard deviation

\begin{tabular}{ccccc}
\multicolumn{5}{l}{ Table 2: Recovery Studies. } \\
\hline $\begin{array}{c}\text { Amount } \\
(\mu \mathrm{g} / \mathrm{ml})\end{array}$ & $\begin{array}{c}\text { Recovery } \\
\text { Level }\end{array}$ & $\begin{array}{c}\text { Amount } \\
\text { spiked } \\
(\mu \mathrm{g} / \mathrm{ml})\end{array}$ & $\begin{array}{c}\text { Amount } \\
\text { recovered } \\
(\mu \mathrm{g} / \mathrm{ml})\end{array}$ & $\begin{array}{c}\% \\
\text { Recovery } \\
(\mathbf{n}=3)\end{array}$ \\
\hline \multirow{3}{*}{100} & $80 \%$ & 80 & $79.5 \pm 0.57$ & 99.37 \\
& $100 \%$ & 100 & $100.3 \pm 0.36$ & 100.30 \\
& $120 \%$ & 120 & $120.1 \pm 0.39$ & 100.08 \\
\hline
\end{tabular}

\begin{tabular}{lccccc}
\multicolumn{3}{l}{ Table 3: Intra and Inter-Day Precision. } \\
\hline Drug & $\begin{array}{c}\text { Amount } \\
(\mu \mathrm{g} / \mathrm{ml})\end{array}$ & \multicolumn{2}{c}{ Intraday $(\mathrm{n}=3)$} & \multicolumn{2}{c}{ Interday $(\mathrm{n}=3)$} \\
\cline { 3 - 6 } & & $\begin{array}{c}\text { Amount found } \\
\text { Mean } \pm \text { SD }\end{array}$ & $\begin{array}{c}\% \\
\text { RSD }\end{array}$ & $\begin{array}{c}\text { Amount found } \\
\text { Mean } \pm \text { SD }\end{array}$ & $\begin{array}{c}\% \\
\text { RSD }\end{array}$ \\
\hline \multirow{4}{*}{ ARM } & 20 & $3082880 \pm 1156$ & 0.17 & $3077213 \pm 9739$ & 0.31 \\
& 50 & $7678476 \pm 65636$ & 0.85 & $7718476 \pm 99992$ & 1.29 \\
& 100 & $15358694 \pm 18317$ & 0.11 & $15392027 \pm 75867$ & 0.49 \\
\hline
\end{tabular}

\begin{tabular}{cc} 
Table 4: Validation Parameters. & \\
\hline Parameter & Armodafinil \\
\hline Retention time & $8.2 \pm 0.1 \mathrm{~min}$ \\
$\mathrm{LOD}(\mu \mathrm{g} / \mathrm{ml})$ & $0.78 \pm 0.01 \mu \mathrm{g} / \mathrm{ml}$ \\
$\mathrm{LOQ}(\mu \mathrm{g} / \mathrm{ml})$ & $2.37 \pm 0.01 \mu \mathrm{g} / \mathrm{ml}$ \\
Linearity & $10-120 \mu \mathrm{g} / \mathrm{ml}, \mathrm{r}^{2}=0.9994$ \\
Accuracy & $100.3 \%$ \\
Intraday precision & $0.11-0.85(\% \mathrm{RSD})$ \\
Inter day precision & $0.31-1.29(\% \mathrm{RSD})$ \\
& Organic phase $( \pm 2 \%) \% \mathrm{RSD} 1.56$ \\
Robust ness & Flow rate $( \pm 0.1 \mathrm{ml}) \% \mathrm{RSD} 1.47$ \\
& $7496 \pm 146$ \\
System Suitability & $<0.5$ \\
& $1.15 \pm 0.1$ \\
\hline
\end{tabular}

Precision

At triplicate concentrations of $20,50,100 \mu \mathrm{g} / \mathrm{ml}$ intra-day and inter-day precision results were obtained. The $\%$ RSD value for both precision was less than $2 \%$ and shown in Table 3 .

\section{Robustness test}

By changing certain properties such as flow rate, mobile phase robustness test was performed for developed method. The method was robust for flow rate parameter tested. 


\begin{tabular}{|c|c|c|c|c|c|c|c|c|c|}
\hline \multirow{3}{*}{$\begin{array}{c}\text { Stress } \\
\text { Condition }\end{array}$} & & \multicolumn{6}{|c|}{$t_{R}(\min )$ of Degradation products } & \multirow[t]{4}{*}{$\%$ degradation } & \multirow[t]{4}{*}{ \% Assay } \\
\hline & No. of & & & $(\%$ & & & & & \\
\hline & \multirow[t]{2}{*}{ Degradants } & 4.4 & 6.61 & 9.8 & 10.4 & 13.3 & 15.7 & & \\
\hline & & D1 & D2 & D3 & D4 & D5 & D6 & & \\
\hline $\begin{array}{c}0.1 \mathrm{~N} \mathrm{HCL} \\
(8 \mathrm{~h})\end{array}$ & 4 & -- & -- & 0.75 & 9.7 & 1.82 & 0.69 & 14.4 & 85.5 \\
\hline $0.01 \mathrm{~N} \mathrm{NaOH}(2 \mathrm{~h})$ & 1 & 27.9 & -- & -- & -- & & -- & 31.7 & 68.2 \\
\hline $\begin{array}{c}3 \% \mathrm{H}_{2} \mathrm{O}_{2} \\
(4 \text { days })\end{array}$ & 1 & -- & 3.43 & -- & -- & -- & -- & 18.4 & 81.5 \\
\hline $\begin{array}{c}\text { Thermal } \\
\left(100^{\circ} \mathrm{C}, 5 \text { days }\right)\end{array}$ & 1 & -- & -- & -- & 10.2 & -- & -- & 10.5 & 89.4 \\
\hline Photolytic(48h) & 1 & -- & -- & -- & -- & -- & 1.23 & 8.29 & 91.7 \\
\hline
\end{tabular}

Limit of detection and limit of quantification

LOQ and LOD were found to be $2.37,0.78 \mu \mathrm{g} / \mathrm{ml}$, respectively.

\section{DISCUSSION}

By using reverse phase mode with water and methanol as a mobile phase the drug was subjected to separation by varying $\%$ aqueous phase from $10 \%$ to $55 \%$. The ARM was separated properly on chromatogram with good peak shape. $55 \%$ of aqueous phase was taken for optimization with RT of $8.2 \mathrm{~min}$. To achieve efficient elution of ARM, various trials were done by varying $\mathrm{pH}$ with appropriate buffers, but there was significant enhancement in theoretical plates and Tailing factor (more than 7000, 1.30 ) when $10 \%$ orthophosphoric acid (OPA) used in mobile phase. In comparison to earlier methods there was one additional impurity revealed in peroxide degradation.

\section{Stress Degradation}

\section{Acidic Degradation}

When treated with $0.1 \mathrm{~N} \mathrm{HCl}$ at room temp for $8 \mathrm{~h}, 14.4 \%$ degradation was observed with formation of four degradants at retention time (in min) of D3 at 9.80, D4 at 10.47, D5 at 13.30 and D6 at 15.78 with respective area percentage of $0.71 \%, 9.70 \%, 1.8 \% 2$ and $0.69 \%$. The assay of ARM was about $85.5 \%$ as shown in Figure 3.

\section{Basic degradation}

When ARM was exposed to $0.01 \mathrm{~N} \mathrm{NaOH}$, the drastic degradation $31.7 \%$ was takes place within $2 \mathrm{~h}$. The percentage area of D1 was $27.9 \%$ at retention time of $4.48 \mathrm{~min}$. The assay of ARM was about $68.2 \%$ shown in Figure 4.

\section{Neutral Degradation}

No degradation was observed when exposed neutral condition for 7 days at room temperature.

\section{Photolytic degradation}

When ARM was exposed to sun light for a period of 48 hours, $8.29 \%$ degradation was observed with formation of one degradant. The retention time $\left(t_{R}\right)$ of D6 was found to be 15.5 min. The assay of ARM was about $91.7 \%$ as shown in Figure 5.

\section{Oxidative degradation}

ARM showed degradation of $18.4 \%$ in $3 \% \mathrm{H}_{2} \mathrm{O}_{2}$ for 4 days. The percentage area of D2 was $3.43 \%$ at retention time of $6.61 \mathrm{~min}$. The assay of ARM was about $81.5 \%$ shown in Figure 6.

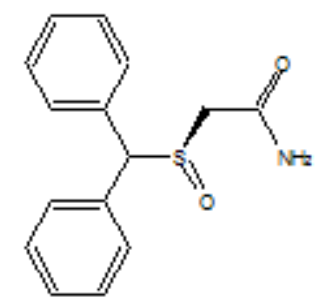

a)

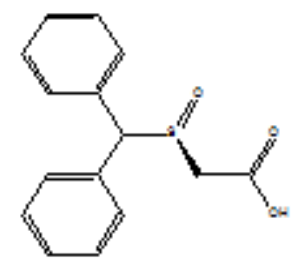

b)

Figure 1: Structure of armodafinil and its base hydrolytic degradant; a) (-)-2-[(R)-(diphenylmethylsulfynil)] acetamide b) 2-[(benzhydrylsulfinyl)] acetic acid (degradant - D1)

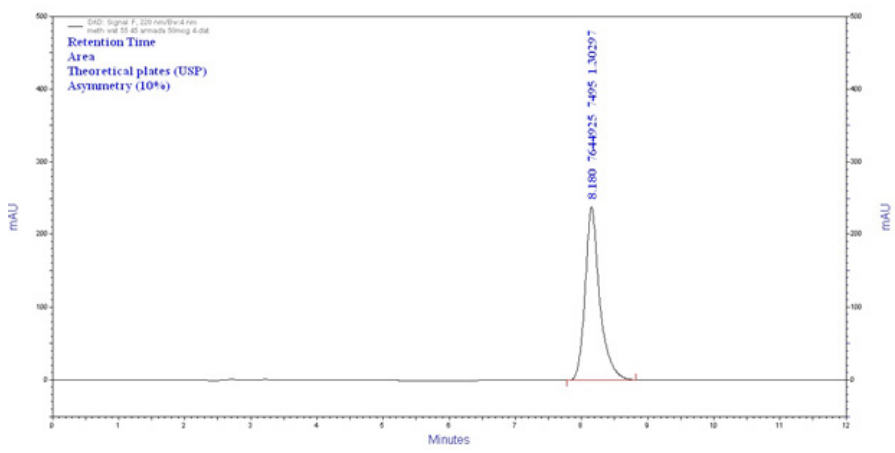

Figure 2: Optimized Chromatogram of Armodafinil.

\section{Thermal degradation}

$\mathrm{ARM}$ was exposed to heat in oven at $100^{\circ} \mathrm{C}$ for 5 days, it was showed $10.5 \%$ degradation with formation of one degradant at retention time of $10.69 \mathrm{~min}$. The assay of ARM was $89.4 \%$ shown in Figure 7. 


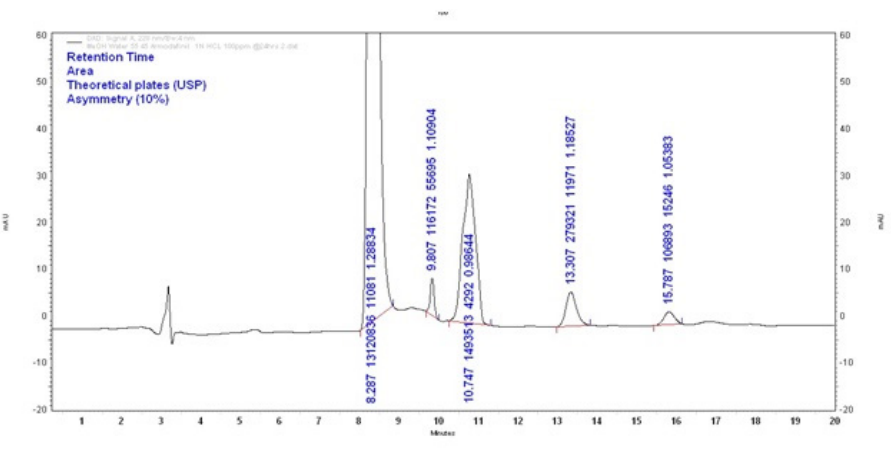

Figure 3: Acid degradation $(0.1 \mathrm{~N} \mathrm{HCl}, 8 \mathrm{~h})$.

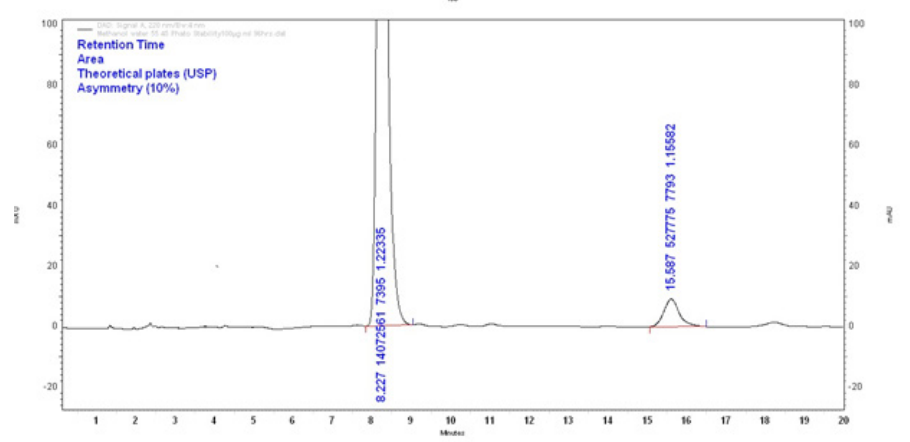

Figure 5: Photolytic degradation (48h).

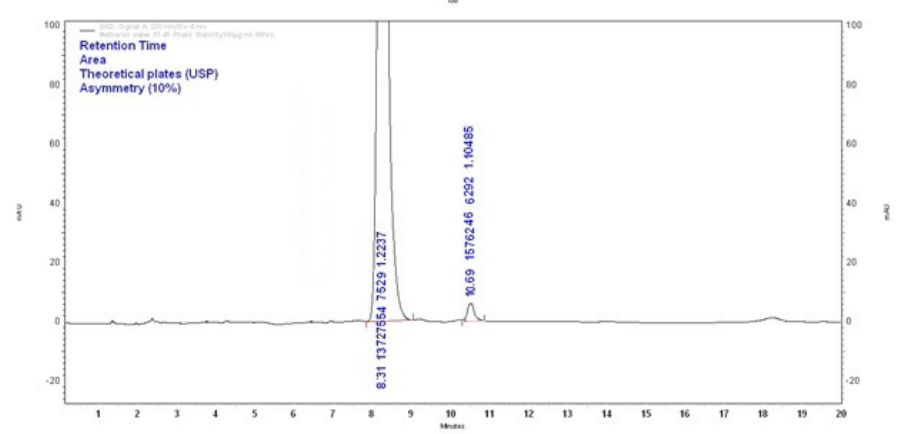

Figure 7: Thermal degradation (1000C, 5 days ).

A total of six degradants were identified in all stress degradation, the drug was more sensitive for basic stress then followed by acid stress, photolytic stress. The ARM was resistant in Neutral conditions.

\section{CONCLUSION}

A new RP-HPLC SIAM method was developed for the estimation of armodafinil in dosage form and validated according to ICH guidelines. This method revealed formation of six possible degradation products after conducting stress studies. The ARM was found to more sensitive to base hydrolysis followed by acid and photolytic degradation. This method is most suitable for stability study of drug after marketing.

\section{ACKNOWLEDGMENT}

The authors extended thanks to IICT, Hyderabad, India for Spectral support.

\section{CONFLICT OF INTEREST}

The authors declare no conflict of interest.

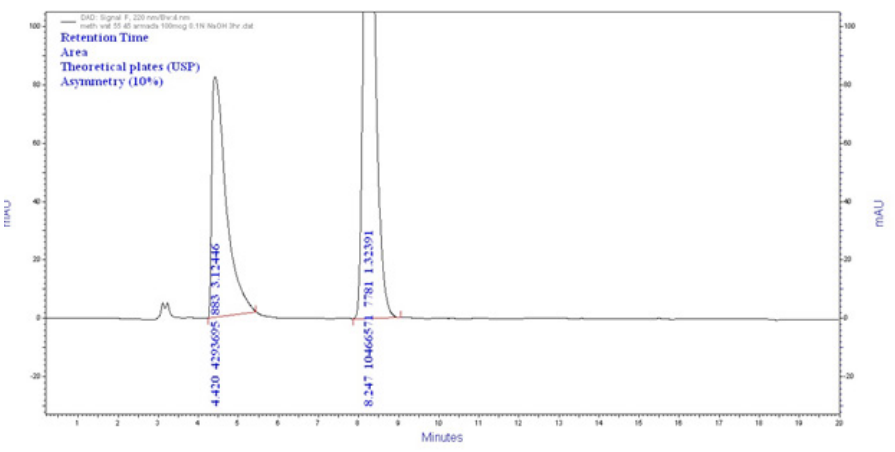

Figure 4: Base degradation $(0.01 \mathrm{~N} \mathrm{NaOH}, 2 \mathrm{~h})$.

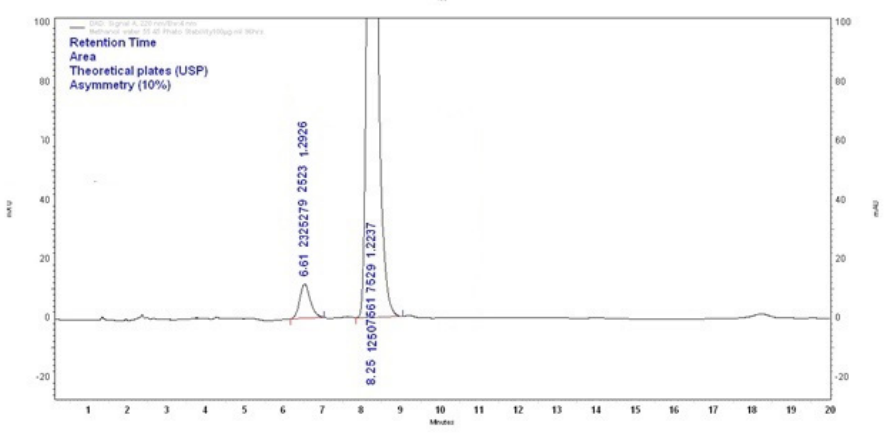

Figure 6: Oxidative degradation (3\% $\mathrm{H} 2 \mathrm{O} 24$ days ).

\section{ABBREVIATION USED}

SIAM: Stability Indicating Assay Method; ARM: Armodafinil.

\section{REFERENCES}

1. Swanson JM. Role of executive function in ADHD. J Clin Psychiatry. 2003;Suppl 64:35-9

2. Wisor JP, Nishino S, Sora I, Uhl GH, Mignot E, Edgar DM. Dopaminergic role in stimulant- induced wakefulness. J Neurosci. 2001;21(5):1787-94.

3. Zhou J, He R, Johnson KM, Ye Y, Kozikowski AP. Piperidine-based nocaine/ modafinil ybrid ligands as highly potent monoamine transporter inhibitors: efficient drug discovery by rational lead hybridization. J Med Chem. 2004; 47(24):5821-4.

4. Overington JP, Al-Lazikani B, Hopkins AL. How many drug targets are there? Nat Rev Drug Discov. 2006;5(12):993-6.

5. Imming P, Sinning $C$, Meyer A. Drugs, their targets and the nature and number of drug targets. Nat Rev Drug Discov. 2006;5(10):821-34

6. Chaudhary $\mathrm{V}$, Ubale M. A validated stability-indicating HPLC assay method for Modafinil $\mathrm{HCl}$ in bulk drug. International journal of pharmaceutical and chemical sciences. 2013;2(1):207-13.

7. Pandya GP, Joshi HS. Stability Indicating HPTLC Method for Estimation of Modafinil in the Bulk and Tablet Formulation. IOSR Journal of Pharmacy and Biological Sciences. 2013;5:22-8.

8. Bennett P, Meng M, Rohde L. Software Assisted Chiral Chromatographic Method Development for the Quantitation of Four Chiral Drugs in Human Plasma Using LC/MS/MS. Tandem labs, Patrick Bennett et al. 2009;41:37.

9. Devadiga MP, Anandan P, Mukhopadhyay A. Development of a rapid and sensitive method for estimation of Armodafinil in human plasma by LCMS/MS. International journal of applied biology and Pharmaceutical technology. 2011;2:323-7.

10. Ramesh D, Ramakrishna S, Mohammad. Development and Validation of LC-MS/MS Method for the Determination of armodafinil in Human Plasma. Current Pharmaceutical Analysis. 2012;8(3):295-305.

11. Afshar M, Salkhordeh N, Rajabi M. An ecofriendly and stability indicating HPLC method for determination of Permethrin isomers: Application to pharmaceutica analysis. Journal of Chemistry. 2012;2013:1-9.

12. Qin S, Gan J. Enantiomeric difference in permethrin degradation pathways in soil and sediment. J Agric Food Chem. 2006;54(24):9145-51.

13. International Conference on Harmonization $\mathrm{Q} 2$ (R1): Validation of analytical procedures: text and, methodology. London. 2005.

14. http://www.ich.org/fileadmin/Public_Web_Site/ICH_Products/Guidelines/Quality/ Q2_R1/Step4/Q2_R1_Guideline.pdf

15. Khan AA, Panda SK, Sahoo SK, Dash AK. Stability indicating RP-HPLC method for determination of modafinil in bulk and its formulations. International Journal 
of Biological and Pharmaceutical Research. 2011;2(1):39-44.

16. Venkateswarlu K, Rangareddy A, Narasimhaiah K, Sharma H, Bandi. NMRA validated stability indicating RP-HPLC method for estimation of Armodafinil in pharmaceutical dosage forms and characterization of its base hydrolytic product. Pak J Pharm Sci. 2017:30(1):23-8.
17. Cass QB, Kohn CK, Calafatti SA, Aboul-Enein HY. An enantioselective assay for ( \pm )-modafinil. J Pharm and Biomed Ana. 2001;26(1):123-30.

18. Jennifer L, Robert J, John S, DeVane C. Donovan, Malcolm, Markowitz, Lindsay Chiral Analysis of $d$-and I-Modafinil in Human Serum: Application to Human Pharmacokinetic Studies. J Ther Drug Monit. 2003;25(2):197-202.

Article History: Submission Date : 08-09-2017 ; Revised Date : 29-09-2017; Acceptance Date : 04-11-2017.

Cite this article: Naik CNP, Sekhar KBC. Reliable and Sensitive Stability Indicating Assay Method of Armodafinil. J Young Pharm. 2018;10(1):52-6. 